\title{
ЕКСПЕРИМЕНТАЛЬНЕ ПОРІВНЯННЯ АЛГОРИТМІВ ВИЗНАЧЕННЯ ОРІЕНТАЦЇ̈ НА БАЗІ КОМПЛІМЕНТАРНОГО ФІЛЬТРУ ТА ФІЛЬТРУ МАДЖВІКА
}

\author{
Бугайов Д.В. ${ }^{1}$, Аврутов В.В. ${ }^{2}$, Нестеренко О.І. ${ }^{3}$ \\ 1,2,3 Національний технічний університет України «Київський політехнічний інститут імені Ігоря Сікорського», м. Київ, \\ Україна \\ ORCID: ${ }^{1}$ http://orcid.org/0000-0002-9691-8654, ${ }^{2}$ http://orcid.org/0000-0002-3875-0646, \\ ${ }^{3}$ http://orcid.org/0000-0002-5564-0182 \\ E-mail: ${ }^{1}$ myscience@engineer.com, ${ }^{2}$ vyshgorod@gmail.com, ${ }^{3}$ oleg.i.nesterenko@gmail.com
}

Copyright (C) 2020 by author and the journal "Automation of technological and business - processes.

This work is licensed under the Creative Commons Attribution International License (CC BY).

http://creativecommons.org/licanses/by/4.0

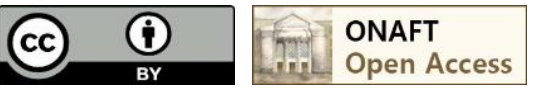

DOI: https://doi.org/10.15673/atbp.v12i3.1921

\begin{abstract}
Анотація. В статті розглядаються питання визначення орієнтації об'єктів. Основними джерелами інформації для розрахунку кутів орієнтації слугують мікроелектромеханічні датчики, а саме мікроелектромеханічний гіроскоп (надає данні про кутову швидкість) та мікроелектромеханічний акселерометр (надає данні про гравітаційне прискорення в нерухомому режимі, та перевантаження в стані руху). Але застосування мікроелектромеханічних датчиків для визначення орієнтації $і$ параметрів руху саме по собі не можливо без використання спеціалізованих алгоритмів обробки отриманих з них сигналів. Головний недолік полягає саме у “якості" отриманих сигналів, тобто наскільки отриманий сигнал з вимірювачів достовірно відображають рух або нерухомий стан об'єкту. Тому алгоритмами визначення орієнтації які запропоновані в роботі для розгляду було обрано алгоритм Компліментарного фільтру та алгоритм фільтру Маджвіка. Використані вимірювальні датчики (гіроскопи $i$ акселерометри) об'єднані в один вимірювальний модуль який в свою чергу є базою для роботи розробки компаніі Inertial Labs - курсовертикалі AHRS-10P. Курсовертикаль AHRS-10P в дослідженні використовується як референтна система, так як вона визначає кути орієнтації об'єкту на якому вона встановлена, за допомогою алгоритму фільтра Калмана і паралельно може видавати сирі данні зняті з акселерометрів $і$ гіроскопів. В результаті дослідження, отримано аналітичні залежності визначеного кута тангажу та кута крену за допомогою алгоритму Компліментарного фільтру та алгоритму фільтру Маджвіка в порівнянні з кутом тангажу та кутом крену отриманими референтною системою AHRS-10P на базі фільтру Калмана.

Abstract. The article deals with the issues of determining the orientation of objects. The main sources of information for calculating the orientation angles are microelectromechanical sensors, microelectromechanical gyroscope (provides data on angular velocity) and microelectromechanical accelerometer (provides data on gravitational acceleration in stationary mode and overload in motion). But the use of microelectromechanical sensors to determine the orientation and motion parameters in itself is not possible without the use of specialized algorithms for processing the signals obtained from them. The main disadvantage is the "quality" of the received signals, in other words how accurate is the received signal from the sensors and how accurately signal reflects the movement or stationary state of the object. Therefore, the Complementary filter algorithm and the Madgwick filter algorithm were chosen for the orientation determination. Measuring sensors which were used (gyroscopes and accelerometers) are combined into one measuring module, which is the basis for the attitude and heading system of the Inertial Labs company-AHRS-10P. The AHRS-10P is used as a reference system in the study, as it determines the orientation angles of the object on which it is mounted, using the Kalman filter algorithm and have ability simultaneously outputs raw data taken from accelerometers and gyroscopes. As a result of the study, the analytical dependences of the determined pitch angle and roll angle were obtained using the Complementary Filter algorithm and the Madgwick filter algorithm in comparison with the pitch angle and roll angle obtained by the reference system AHRS-10P based on Kalman filter.
\end{abstract}

Ключові слова: Компліментарний фільтр, фільтр Маджвіка, фільтр Калмана, МЕМС гіроскоп, МЕМС акселерометр, орієнтація.

Keywords: Complimentary filter, Madgwick filter, Kalman filter, MEMS gyroscope, MEMS accelerometer, orientation. 
http://www.atbp.onaft.edu.ua/

\section{1. Вступ}

За період минулого десятиліття галузь області навігації стала не можливою без використання інерціальних вимірювачів [1] побудованих на базі мікроелектромеханічних систем (МЕМС) - гіроскопів та акселерометрів. Які являють собою легкі, мініатюрні вимірювачі фізичних величин пов'язаних з рухом об'єктів де вони встановлені. Їх використання в першу чергу пояснюється трендом на мініатюризацію та постійно зростаючим попитом на легкі повітряні та наземні апарати для застосування в абсолютно різних галузей суспільства. 3 іншого боку це пояснюється запитом на розробку автономних автопілотних систем, де вплив на процес керування і саму присутність людини буде мінімізовано до нуля [2]. Але застосування МЕМС-датчиків для визначення параметрів руху саме по собі не можливо без використання спеціалізованих алгоритмів обробки отриманих з них сигналів. Головний недолік полягає саме у “якості” отриманих сигналів, тобто наскільки отриманий сигнал з вимірювачів достовірно відображають рух або нерухомий стан об’єкту. А для процесу керування високоточна інформація про параметри руху повинна надходити безперебійно. Так як визначення орієнтації об'єкту є одним з елементів комплексної задачі, що стосується автономної роботі механізованих систем чи повітряно-наземних апаратів, дослідження алгоритмів їі визначення $є$ актуальним завданням. Широку популярність в цьому напрямку завоював фільтр Калмана [3]. Він дійсно дає непогані результати, але все ж таки i має недоліки які будуть показані далі. Саме ці факти і заставляють проводити пошуки альтернативних, максимально ефективних алгоритмів визначення орієнтації.

\section{2. Проблематика}

Визначення кутів нахилу (орієнтаціі) об’єкту можливе за допомогою гіроскопів, або за допомогою акселерометрів. У першому випадку кут нахилу обчислюється за допомогою дискретного інтегрування кутової швидкості, що визначається саме гіроскопом.

Однак, у MEMS гіроскопа є негативна технічна особливість - нестабільний дрейф нуля [4]. Суть цього недоліку зводиться до того, що при відсутності обертового руху об'єкта, на виході гіроскопу все ще буде наявне значення відмінне від нуля. Іншим недоліком використання лише гіроскопу, $є$ застосування процедури дискретного інтегрування виміряної кутової швидкості, яка за своєю природою дає неточний результат. Третя проблема тісно пов'язана з попередньою. Вона виражається в поступовому накопиченні помилки обчислення кута через обмеження точності змінних мікроконтролера.

Якщо використовувати лише акселерометр, то для визначення кута нахилу досить застосувати прості геометричні перетворення для обрахунку, що дуже просто на практиці. Але акселерометр дозволяє визначати точні кути нахилу приладу тільки в стані спокою. Так як, в стані спокою на нього не діють зовнішні сили, і тому на виході датчика представлене лише значення проекції прискорення вільного падіння на спостережувану вісь.

Таким чином, на основі одного лише акселерометра можна також досить легко обрахувати кут нахилу. Але, на жаль, будь-який вплив зовнішньої сили вносить в ці обчислення непередбачувану помилку. Такими зовнішніми силами, наприклад, можуть бути вібрація від двигунів об'єкта або раптовий порив вітру. Частково зняти цей вплив можна за допомогою фільтру нижніх частот (ФНЧ), але побічним ефектом подібної обробки сигналу буде сильне зменшення швидкодії, тобто значення визначеного кута буде обраховуватися 3 великою затримкою, що не $є$ перевагою в задачах в режимі реального часу.

В результаті є два сенсори, кожен з яких дозволяє розрахувати кути нахилу об'єкту, де вони встановлені, відносно поверхні землі. Але в разі гіроскопа точність таких розрахунків знижується через дрейф нуля і помилок інтегрування. У разі ж акселерометра занадто велика чутливість до зовнішніх впливів.

Тому з метою мінімізації всіх вищесказаних недоліків, чутливі елементи намагаються алгоритмічно поєднати в єдину систему, так щоб йшло доповнення одного датчика другим і виділяються лише їх позитивні сторони [5].

\section{3. Постановка задачі}

Метою даної роботи є реалізація алгоритмів визначення орієнтації на базі Компліментарного фільтру та фільтру Маджвіка і порівняти їх працездатність з референтною системою на базі фільтру Калмана.

\section{4. Класифікація алгоритмів визначення оріснтації}

Існуючі алгоритми визначення орієнтації мають певні спільні риси. До спільних сторін відноситься те, що головним джерелом інформації для їх роботі є гіроскопи та акселерометри (додатковим джерелом інформації може бути і магнітометр), мета всіх алгоритмів полягає в доповненні одних сигналів іншими для підвищення точності. Але все ж таки головна ідея нівелювання помилок різниться. На цьому базисі, проводячи літературний аналіз можна виокремити таку структуру існуючих алгоритмів визначення орієнтації з поєднанням сигналів різних датчиків [5], [6]:

1. алгоритми на базі фільтру Калмана та на основі його модифікацій;

2. алгоритм Компліментарного фільтру (також в літературі відомий як Альфа-Бета фільтр);

3. алгоритм матриці напрямних косинусів (інколи зустрічається під назвою фільтр Премерлані і Бізарда);

4. фільтр Махоні;

5. фільтр Маджвіка.

Як було сказано раніше, фільтр Калмана має широку сферу застосування, і $є$ одним з еталонних алгоритмів для визначення орієнтації через те, що він має високу достовірність показань, проявляє гарні фільтраційні можливості, оцінює і прогнозує стан системи, має безліч різних реалізацій, що дозволяють підібрати фільтр для певного завдання. Але не дивлячись на це все, недоліки фільтра також є значимими, що проявляються в складному налаштуванні, для 
http://www.atbp.onaft.edu.ua/

функціонування потрібно швидкодіючий обчислювальний пристрій, необхідна висока частота дискретизації для ефективного оперування, яка може перевищувати фізичні можливості об'єкта, обов'язкова наявність математичної моделі датчиків, що створює складності при імплементації нових зразків чутливих елементів [7].

В даній роботі розглядаються алгоритми на основі Компліментарного фільтра та фільтра Маджвіка, через те що перший не потребує складного налаштування та є легковагим по відношенню до обчислювальних ресурсів; другий же, $\epsilon$ одним з останніх представників розроблених алгоритмів і поступово набирає все більшу популярність.

\section{5. Алгоритм Компліментарного фільтру}

Головне завдання комплементарного фільтра полягає в тому, щоб нівелювати дрейф нуля гіроскопа і помилки процедури дискретного інтегрування. Це досягається за рахунок того, що обраховане значення кута нахилу являє собою сукупність кута отриманого інтегруванням кутової швидкості виміряної гіроскопом і складовою миттєвого значення кута обрахованого за допомогою акселерометрів. Це можна виразити наступною формулою [8]:

$$
\hat{\varphi}_{t}=K\left(\hat{\varphi}_{t-1}+\omega_{t} \cdot \Delta t\right)+(1-K) \varphi_{a, t}
$$

Тут складові формули означають наступне:

1) $\hat{\varphi}_{t}$ - шукана оцінка значення кута в момент часу $t$.

2) $\hat{\varphi}_{t-1}-$ оцінка значення кута на попередньому кроці алгоритму.

3) $\omega-$ значення кутової швидкості, отримане з показань гіроскопа в момент часу $t$.

4) $\Delta t$ - частота дискретизації.

5) $K$ - коефіцієнт комплементарного фільтра (знаходиться в межах від 0 до 1).

6) $\varphi_{a}-$ значення кута нахилу, отримане за показаннями акселерометра в момент часу $t$.

На рис. 1 показано блок-схему повної реалізації Компліментарного фільтру на базі використання даних 3 інерціальних датчиків (гіроскопів та акселерометрів) для визначення оціненого кута орієнтації об'єкту.

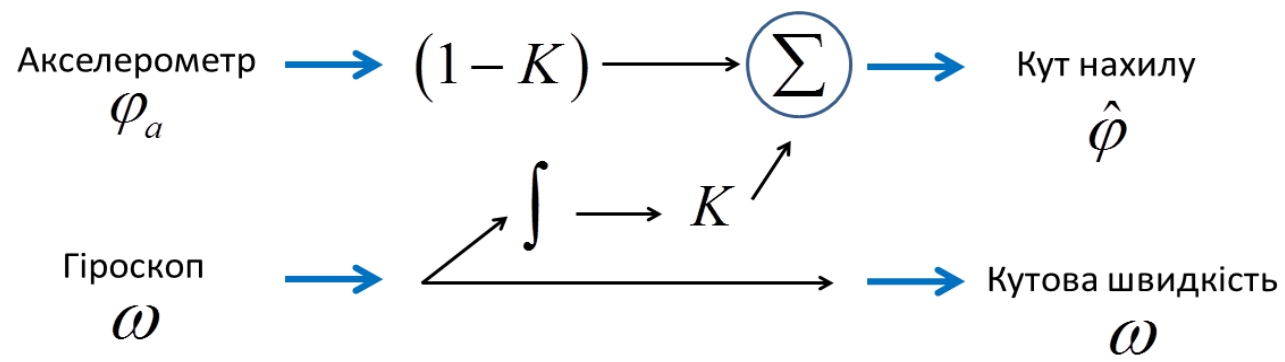

Рис. 1 - Блок-схема комплементарного фільтру

Значення коефіцієнта комплементарного фільтра може бути виражено через частоту дискретизації сигналу:

$$
K=\frac{\tau}{\tau+\Delta t}
$$

де $\tau$ - це постійна часу.

Постійна часу фільтра відображає відносну тривалість затримки реакції фільтру, на вхідні сигнали. Це значення слід спостерігати експериментально, а його типовий діапазон становить від 0,5 до 1 сек [9], [10].

Таким чином, видно, що в кожен момент часу Компліментарний фільтр проводить корекцію сигналу отриманого 3 гіроскопу за допомогою показань отриманих 3 акселерометрів. Сила ж цієї корекції визначається коефіцієнтом фільтра $K$.

Вибір коефіцієнта $K$ залежить від величини дрейфу нуля гіроскопа, від швидкості накопичення помилок обчислення і від умов в момент використання. Так, занадто велике значення $K$ призведе до того, що на результат роботи фільтру буде сильно впливати зовнішні чинники, наприклад вібрація корпусу об'єкту на якому встановлена система. Занадто ж мале значення $K$ може виявитися недостатнім, щоб проводити корекції дрейфу нуля гіроскопа. Як правило, коефіцієнт комплементарного фільтра підбирається вручну для кожного випадку окремо виходячи 3 вищевказаних умов [11], [12].

\section{5. Алгоритм фільтру Маджвіка}

Фільтр Маджвіка поступово привертає до себе все більше уваги з боку розробників інерціальних систем для вирішення задачі орієнтації. Фільтр має 2 варіанти імплементації [3]:

- в першому варіанті, для розрахунку кутів орієнтації об'єкта використовуються показання лише 3 інерціальних датчиків (гіроскопи та акселерометри);

- в другому варіанті, для розрахунку кутів орієнтації об'єкта, показання з інерціальних датчиків доповнюються показаннями магнітометра. Це додатково дає можливість коригувати точність визначення кута курсу об'єкта. 
В алгоритмі кути орієнтації представленні в кватерніонному вигляді, це дає додаткову перевагу над кутами Ейлера, що проявляться в виключенні можливості ситуації складання рамок (блокування обертання, англ. gimbal lock) [13], [14].

Детально фільтр Маджвіка описаний в роботі [15]. За структурою роботи, головним завданням фільтру $\epsilon$ визначення оцінки кватерніону орієнтації в певний момент часу, ${ }_{E}^{S} q_{e s t, t}$. В позначенні прийнято, що передній нижній індекс позначає цільову систему відліку, а передній верхній індекс позначає систему відліку що пов'язана безпосередньо з об'єктом обертання. Далі в тексті індекс S позначає систему відліку пов'язану з вимірювальними датчиками (від англ. sensor), а індекс Е систему відліку пов'язану з Землею (від англ. Earth).

Оцінка кватерніону орієнтації ${ }_{E}^{S} q_{e s t, t}$ виконується шляхом численного інтегрування розрахованої швидкості зміни орієнтації об'єкту, ${ }_{E}^{S} \dot{q}_{e s t, t}$. Швидкість зміни орієнтації об’єкту може бути визначена за наступною формулою:

$$
{ }_{E}^{S} \dot{q}_{e s t, t}={ }_{E}^{S} \dot{q}_{\omega, t}-\beta{ }_{E}^{S} \dot{\hat{q}}_{\varepsilon, t},
$$

тут складові формули означають наступне:

1) ${ }_{E}^{S} \dot{q}_{\omega}$ - швидкість зміни орієнтації, яка обрахована за показаннями гіроскопічного датчика. Індекс $\omega$ вказує на те що кватерніон розраховується 3 виміряних кутових швидкостей. Обрахунок цього параметру здійснюється за наступною формулою:

$$
{ }_{E}^{S} \dot{q}_{\omega, t}=\frac{1}{2}{ }_{E}^{S} \hat{q}_{e s t, t-1} \otimes{ }^{S} \omega_{t},
$$

де, в кватерніонному множенні задіяна нормована оцінка кватерніону орієнтації на попередньому кроці обрахунку ${ }_{E}^{S} \hat{q}_{e s t, t-1}=\left[\begin{array}{llll}q_{1} & q_{2} & q_{3} & q_{4}\end{array}\right]$, та вектор кутових швидкостей ${ }^{S} \omega=\left[\begin{array}{llll}0 & \omega_{x} & \omega_{y} & \omega_{z}\end{array}\right]$ виміряних на кожній 3 осей в певний момент часу $t$.

2) ${ }_{E}^{S} \dot{\hat{q}}_{\varepsilon}$ - нормована оцінка швидкість зміни орієнтації, яка обчислюється на підставі вимірів акселерометрів (i магнітометрів якщо використовується розширена модель фільтра Маджвіка). Розрахунок проводиться за наступною формулою (без урахування показників магнітометрів):

$$
{ }_{E}^{S} \dot{\hat{q}}_{\varepsilon, t}=\frac{\nabla f}{\|\nabla f\|}=\frac{J_{g}^{T}\left({ }_{E}^{S} \hat{q}_{e s t, t-1}\right) f_{g}\left({ }_{E}^{S} \hat{q}_{e s t, t-1},{ }^{S} \hat{a}_{t}\right)}{\left\|J_{g}^{T}\left({ }_{E}^{S} \hat{q}_{e s t, t-1}\right) f_{g}\left({ }_{E}^{S} \hat{q}_{e s t, t-1},{ }^{S} \hat{a}_{t}\right)\right\|},
$$

де, проводиться розрахунок градієнту поверхні рішень $\nabla f$, визначених цільовою функцією $f_{g}\left({ }_{E}^{S} \hat{q},{ }^{S} \hat{a}\right)$ та i якобіаном $J_{g}^{T}\left({ }_{E}^{S} \hat{q}_{e s t, t-1}\right)$, в залежності нормованих значення показань з акселерометрів ${ }^{S} \hat{a}=\left[\begin{array}{llll}0 & a_{x} & a_{y} & a_{z}\end{array}\right]$ та нормованого значення кватерніону орієнтації розрахованого на попередньому кроці алгоритму $\underset{E}{S} \hat{q}=\left[\begin{array}{llll}q_{1} & q_{2} & q_{3} & q_{4}\end{array}\right]$ в певний момент часу $t$. Повні вирази розрахунку цільової функції та ії якобіану є наступними:

$$
f_{g}\left({ }_{E}^{S} \hat{q},{ }^{S} \hat{a}\right)=\left[\begin{array}{c}
2\left(q_{2} q_{4}-q_{1} q_{3}\right)-a_{x} \\
2\left(q_{1} q_{2}+q_{3} q_{4}\right)-a_{y} \\
2\left(\frac{1}{2}-q_{2}^{2}-q_{3}^{2}\right)-a_{z}
\end{array}\right], \quad J_{g}^{T}\left({ }_{E}^{S} \hat{q}\right)=\left[\begin{array}{cccc}
-2 q_{3} & 2 q_{4} & -2 q_{1} & 2 q_{2} \\
2 q_{2} & 2 q_{1} & 2 q_{4} & 2 q_{3} \\
0 & -4 q_{2} & -4 q_{3} & 0
\end{array}\right]
$$

3) $\beta$ - встановлена помилка вимірювання гіроскопа. Цей параметр являє собою коефіцієнт посилення фільтра, що представляє собою сукупність всіх помилок вимірювань нуля гіроскопа. Можливими джерела появи помилки може бути: шум датчика, тип згладжуючого фільтру, помилки квантування, помилки калібрування, помилки установки і вирівнювання датчика, не ортогональність осей датчика і частотні обмеження сигналу. Розрахунок проводиться за наступною формулою:

$$
\beta=\left\|\frac{1}{2} \hat{q} \otimes\left[\begin{array}{llll}
0 & \tilde{\omega}_{\beta} & \tilde{\omega}_{\beta} & \tilde{\omega}_{\beta}
\end{array}\right]\right\|=\sqrt{\frac{3}{4}} \tilde{\omega}_{\beta}
$$

де, в кватерніонному множенні $\hat{q}$ та $\tilde{\omega}_{\beta}$ позначено одиничний кватерніон та оцінку середньої похибки вимірювання нуля гіроскопа по кожній осі відповідно. 
На рис. 2 показано блок-схему повної реалізації фільтру Маджвіка на базі використання даних 3 інерціальних датчиків (гіроскопів та акселерометрів) для визначення оціненого кватерніону орієнтації об'єкту.

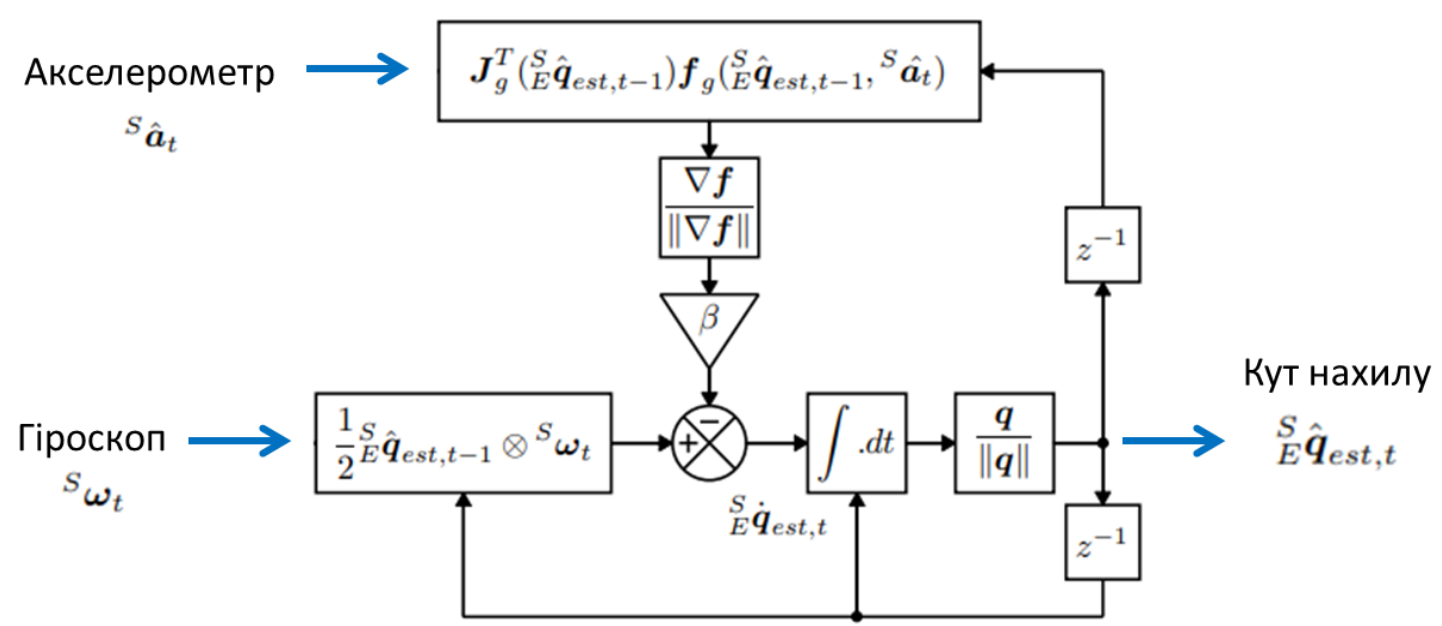

Рис. 2 - Блок-схема фільтру Маджвіка (без урахування магнітометрів) [15]

\section{6. Відомості про референтну систему}

В якості референтної системи була використана розробка компанії Inertial Labs - курсовертикаль AHRS-10P [16]. Основні техніко-технічні показники та сам прилад показано на рис. 3.

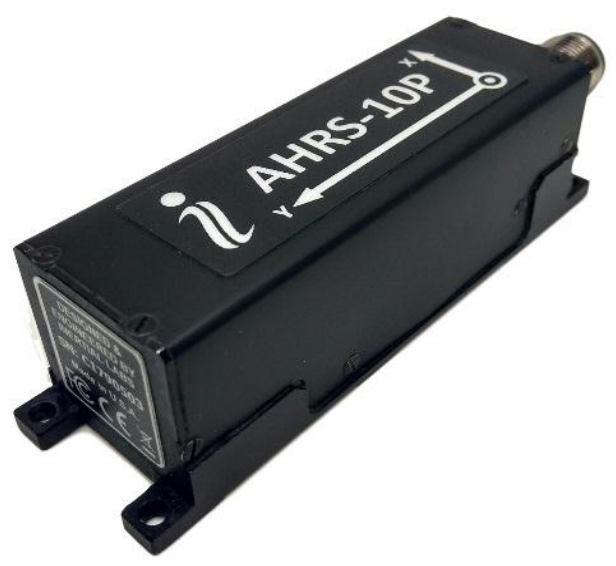

Точність розрахунку кутів:

\begin{tabular}{|r|c|l|}
\hline курс & $0.3^{\circ}$ в статиці & $0.6^{\circ}$ в динаміці \\
\hline крен та тангаж & $0.05^{\circ}$ в статиці & $0.08^{\circ}$ в динаміці \\
\hline
\end{tabular}

Нестабільність нуля ЧЕ:

\begin{tabular}{|r|l|}
\hline Гіроскопи & $1^{\circ} /$ год \\
\hline Акселерометри & $0.005 \mathrm{mg}$ \\
\hline
\end{tabular}

Тип магнітометру:

Магнітний компас

\section{Рис. 3 - Техніко-технічні показники курсовертикалі Inertial Labs AHRS-10P}

Курсовертикаль використовує 3-х осьові прецизійні чутливі елементи як, акселерометри, магнітометри та гіроскопи для забезпечення визначення кутів нахилу (курсу, крену та тангажу) об’єкта на якому вона встановлена під керівництвом розширеного алгоритму синтезу показань датчиків на основі фільтру Калмана. Ефективна при використанні як в рухомих так і статичних операціях.

\section{7. Методологія проведеного експерименту}

В якості експерименту було проведено запис інформації з чутливих елементів AHRS-10Р при ії довільному нахилі по кут крену та тангажу на робочому столі. Слід зазначити, що подальші розрахунки були побудовані на базі показань отриманих лише з акселерометрів і гіроскопів, так як для забезпечення відсутності магнітних збурень навколишнього середовища на магнітометри потрібно було проводити процедуру їх калібрування, що потребує додаткового обладнання. I через те, що магнітометри використовуються лише для корекції кута курсу, то для чистоти експерименту, значення кута курсу не буде визначатись та піддаватись аналізу.

Після зняття інформації, сирі данні з акселерометрів і магнітометрів були заведені в розроблений алгоритм Компліментарного фільтру та фільтру Маджвіка для обрахунку кутів крену та тангажу. Отримані значення кутів порівнювались зі значеннями наданими курсовертикаллю після роботи іiі алгоритму на базі фільтру Калмана.

\section{8. Отримані результати}

На рис. 4 показані значення кутових зміщень у часі на кут тангажу (англ. pitch) та крену (англ. roll) з референтної системи AHRS-10P. Саме ці данні будут використанні для порівняльної характеристики отриманих значень кутових відхилень у часі за допомогою Компліментарного фільтру та фільтру Маджвіка. 

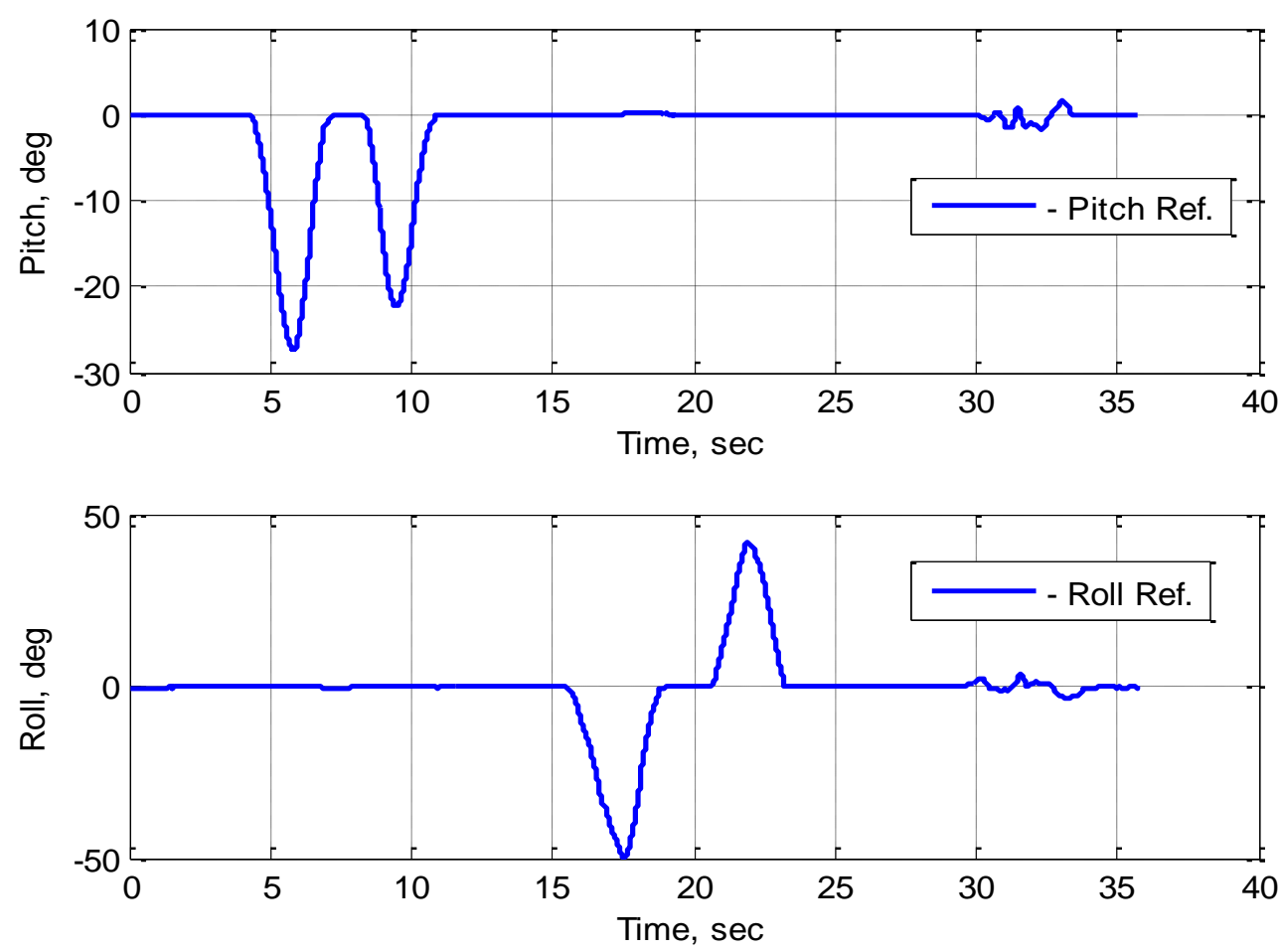

Рис. 4 - Значення кутів з референтної системі на базі алгоритму фільтру Калмана - Inertial Labs AHRS-10P

На рис. 5 та рис.6 показаний результат виконання алгоритму на базі Компліментарного фільтру для кута тангажу на крену відповідно. Також показано відмінність отриманих даних з референтною системою.
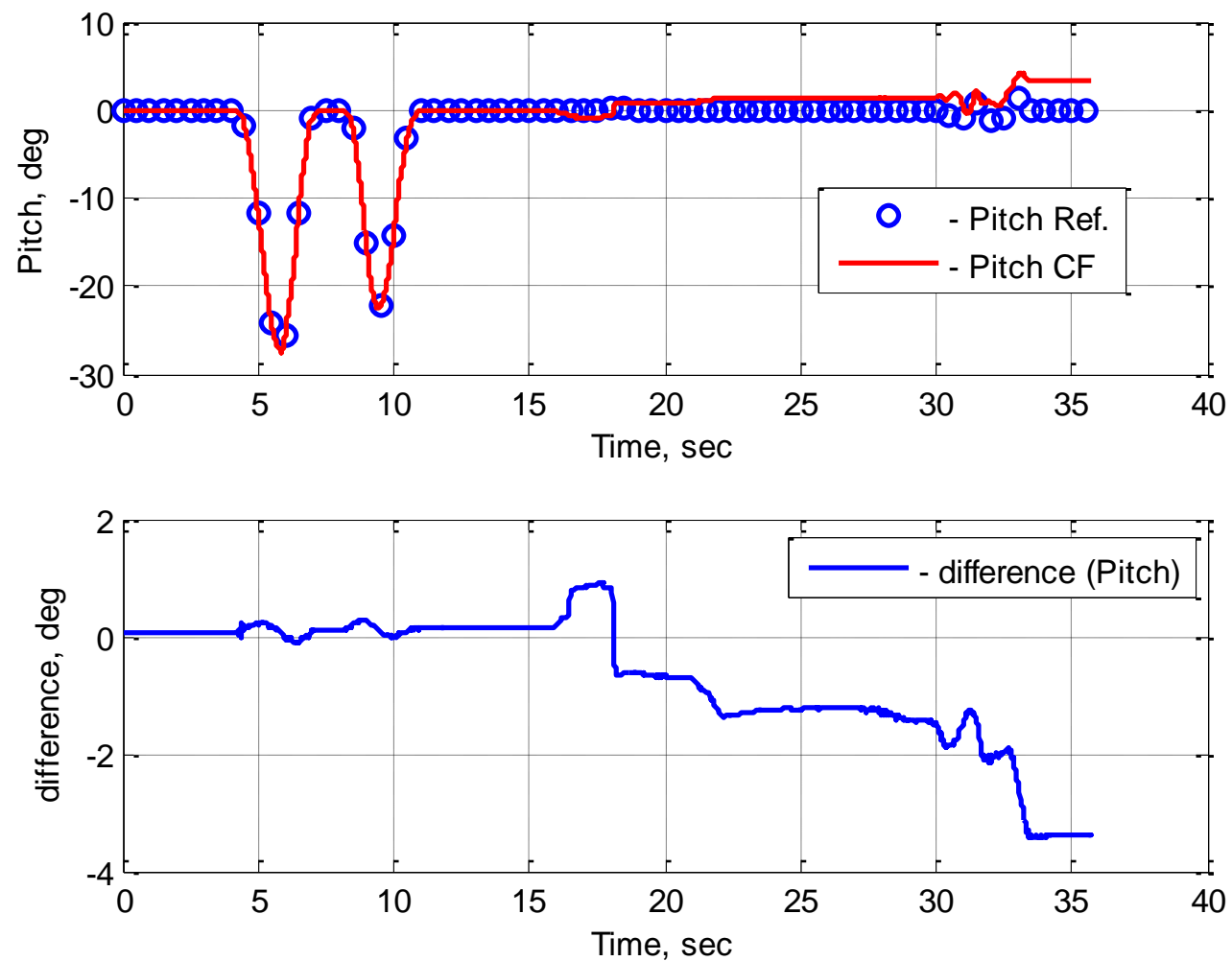

Рис. 5 - Отримане значення кута тангажу за допомогою алгоритму Компліментарного фільтру та різниця показань 3 референтною системою 

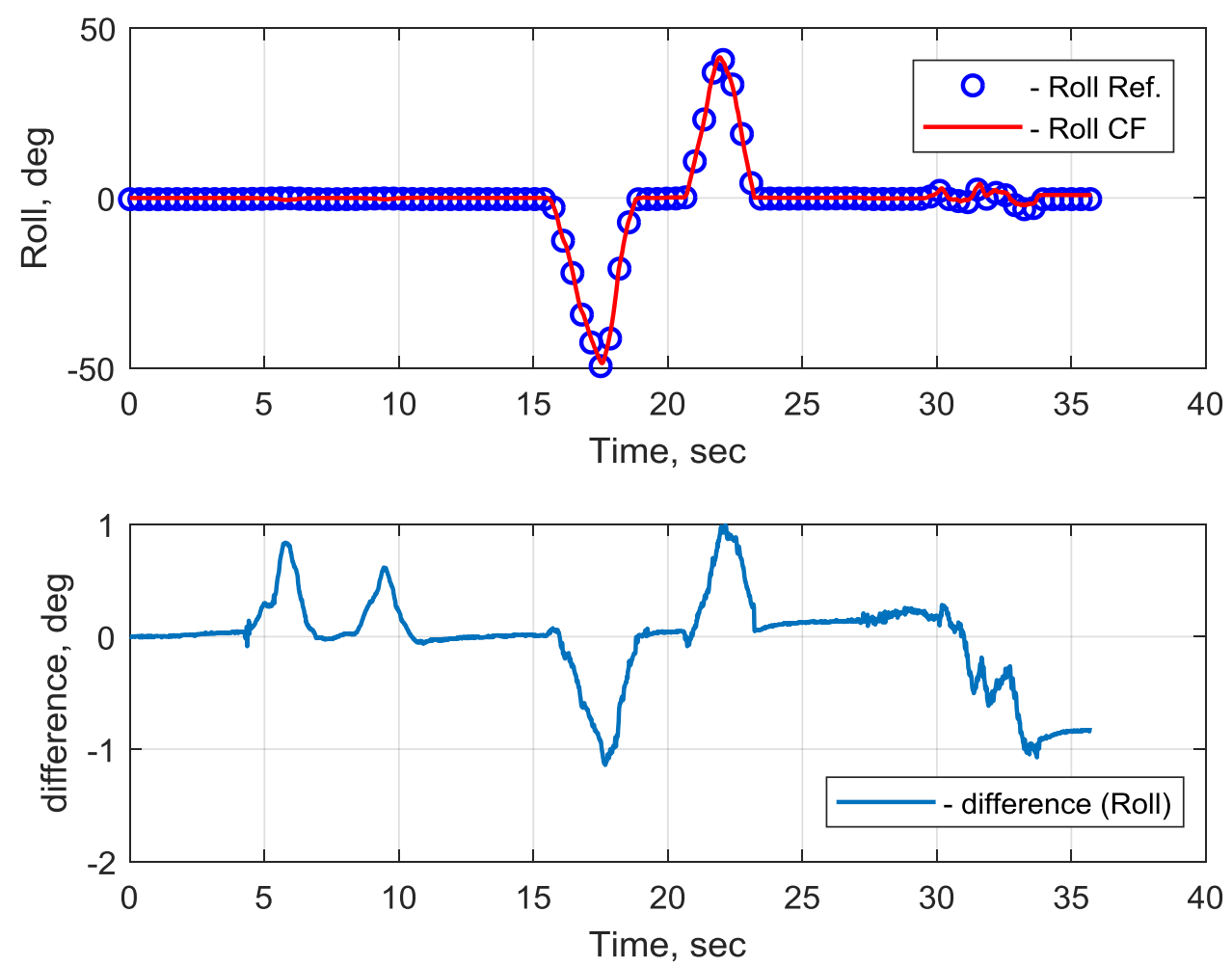

Рис. 6 - Отримане значення кута крену за допомогою алгоритму Компліментарного фільтру та різниця показань 3 референтною системою

На рис. 7 та рис. 8 показаний результат виконання алгоритму на базі фільтру Маджвіка для кута тангажу на крену відповідно. Також показано відмінність отриманих даних з референтною системою.
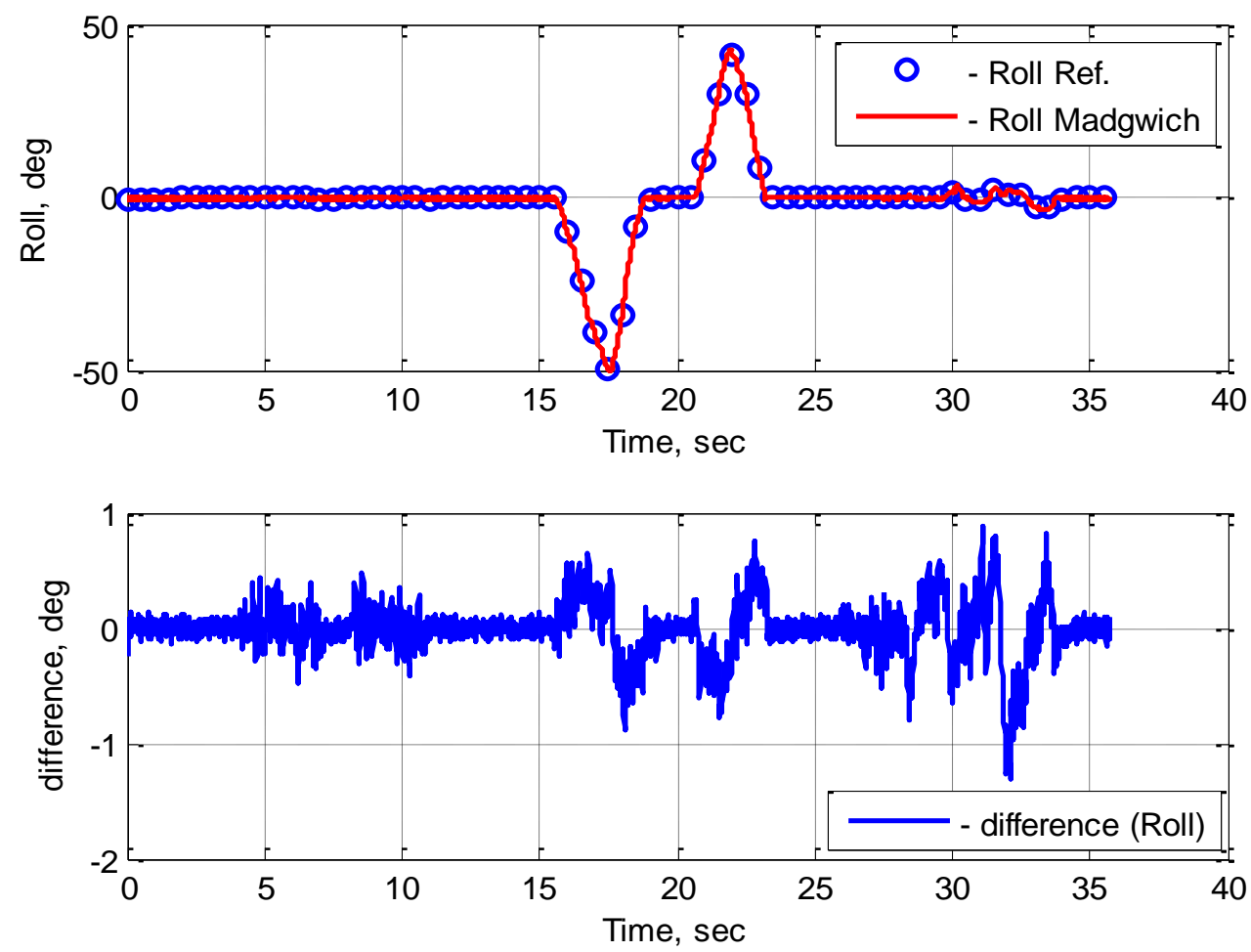

Рис. 7 - Отримане значення кута тангажу за допомогою алгоритму фільтру Маджвіка та різниця показань 3 референтною системою 

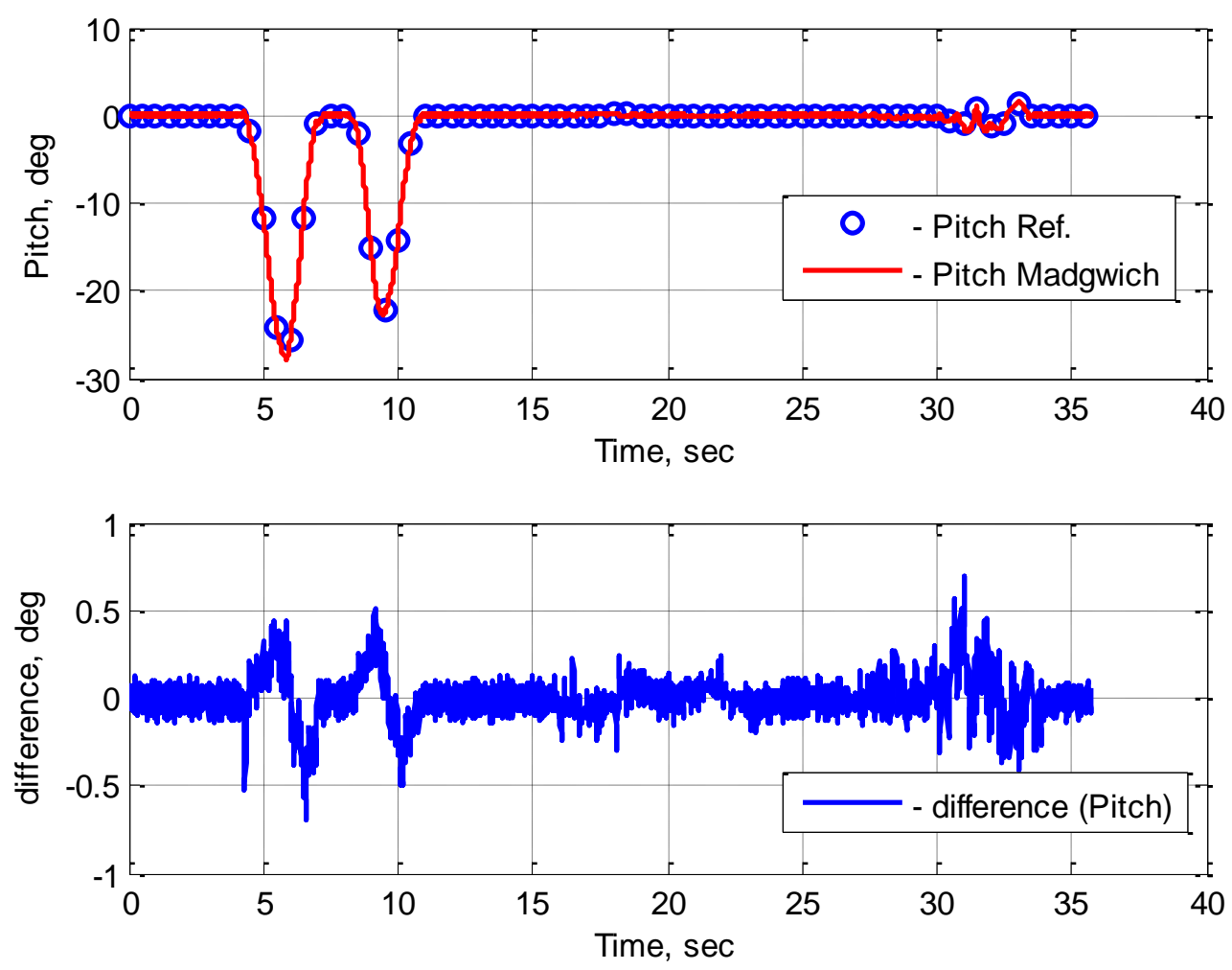

Рис. 8 - Отримане значення кута крену за допомогою алгоритму фільтру Маджвіка та різниця показань 3 референтною системою

Доцільно провести математичне порівняння отриманих значень. Для цього проведемо розрахунок коефіцієнту кореляції Пірсона для кожного алгоритму в порівнянні з референтним за наступною формулою:

$$
\rho(A, B)=\frac{1}{N-1} \sum_{i=1}^{N}\left(\frac{A_{i}-\mu_{A}}{\sigma_{A}}\right)\left(\frac{B_{i}-\mu_{B}}{\sigma_{B}}\right),
$$

де через $A$ та $B$ позначено порівнювані вибірки; через $\mu_{A}$ та $\sigma_{A}$ позначено середнє і стандартне відхилення для $A, \mathrm{i}$ через $\mu_{B}$ та $\sigma_{B}$ позначено середне і стандартне відхилення для $B ; N$ - кількість точок вибірки (для $A$ та $B$ значення повинно бути однаковим).

Значення коефіцієнту кореляції Пірсона лежить в проміжку $0 \leq \rho(A, B) \leq 1$, де значення максимально наближене до одиниці вказує на високу ступінь лінійної залежності між порівнюваними вибірками, і навпаки значення наближене до нуля вказує на низьку ступінь лінійної залежності між порівнюваними вибірками. Результат обрахунку наведено в таблиці 1.

Таблиця 1 - Коефіціснти кореляції

\begin{tabular}{|l|c|c|}
\hline \multirow{2}{*}{ Досліджуваний алгоритм } & \multicolumn{2}{|c|}{ Референтний алгоритм: Фільтр Калмана } \\
\cline { 2 - 3 } & Кут крену & Кут тангажу \\
\hline Компліментарний фільтр & 0,9844 & 0,9996 \\
\hline Фільтр Маджвіка & 0,9998 & 0,9997 \\
\hline
\end{tabular}

\section{Висновки}

В даній роботі були розглянуті три види алгоритмів визначення орієнтації: на базі фільтру Калмана, на базі Компліментарного фільтру та на базі фільтру Маджвіка. У якості еталонної (референтної) системи для перевірки роботи розроблених алгоритмів була використана курсовертикаль AHRS-10P яка в собі вже вміщує алгоритм роботи на базі фільтру Калмана. Отримані результати показали що всі алгоритми мають гарні властивості обрахунку кутів орієнтації. Фільтр Маджвіка показав майже ідентичні показання з референтною системою.

В подальших дослідженнях доцільно буде провести аналіз роботи фільтрів по визначенню кутів нахилу об’єкта котрий знаходиться в рухомому стані, і визначити ступінь компенсації похибок інерціальних сенсорів розглянутими алгоритмами комплексування. 
http://www.atbp.onaft.edu.ua/

\section{Список використаних джерел:}

[1] Collin, J., Davidson, P., Kirkko-Jaakkola, M., Leppäkoski H. Inertial sensors and their applications. In Handbook of Signal Processing Systems, Springer, Cham. 2019. C. 51-85.

[2] El-Sheimy, N., Youssef, A. Inertial sensors technologies for navigation applications: state of the art and future trends. Satellite Navigation. 2020. №1(1), 2.

[3] Яцына, Ю., Гриднев, Ю., Шведко, А. Сравнительный анализ дискретных фильтров Калмана и Маджвика. Наука и инновации. 2017. № 2(168).

[4] Сергеенков, Д. Д. Экспериментальное сравнение алгоритмов определения ориентации для мультикоптеров. Международный журнал информачионных технологий и энергоэффективности. 2019. № 4(2). С. 31-40.

[5] Кориков, А. М., Мещеряков, Я. Е. Ориентация горных технологических машин на основе микроэлектромеханических систем. Доклады Томского государственного университета систем управления и радиоэлектроники. 2018. № 21(4).

[6] Мещеряков Я.Е. Автоматизация процессов мониторинга и позиционирования функциональных элементов горных технологических машин: автореф. дис. канд. техн. наук. Томск, 2018.

[7] Радзівілов, Г. Д., Фесенко, О. Д. Компенсація похибок інерціальних вимірювальних датчиків МЕМС на основі фільтра Маджвіка. Збірник наукових прац̧ь Військового інституту телекомунікацій та інформатизаиії. 2018. № 1. C. 77-82.

[8] Malinen, E. Fusion of data from quadcopter's inertial measurement unit using complementary filter. Bachelor's Thesis, Lappeenranta University of Technology, Finland. 2015.

[9] Urdhwareshe, R., Bakshi, M., Naiknavare, P., Naik, S. Design and implementation of IMU sensor fusion and PID control in quadrotor. Int. J. Electron. Commun. 2014. № 2. C. 55-63.

[10] Mai, T. A., Dang, T. S., Anisimov, D. N., Fedorova, E. Fuzzy-PID Controller for Two Wheels Balancing Robot Based on STM32 Microcontroller. International Conference on Engineering Technologies and Computer Science (EnT). IEEE. 2019. C. 20-24. DOI: 10.1109/EnT.2019.00009

[11] Baerveldt, A. J., Klang, R. A low-cost and low-weight attitude estimation system for an autonomous helicopter. Proceedings of IEEE International Conference on Intelligent Engineering Systems. IEEE. 1997. C. 391-395.

[12] Min, H. G., Jeung, E. T. Complementary filter design for angle estimation using mems accelerometer and gyroscope. Department of Control and Instrumentation, Changwon National University, Changwon, Korea. 2015. C. 641-773.

[13] Гордеев В. Н. Кватернионы и бикватернионы с приложениями в геометрии и механике. Киев: Издательство "Сталь". 2016. 316 с. ISBN 978-617-676-099-3.

[14] Perumal, L. Quaternion and its application in rotation using sets of regions. International Journal of Engineering and Technology Innovation. 2011. № 1(1), 35.

[15] Madgwick, S. An efficient orientation filter for inertial and inertial/magnetic sensor arrays. Report x-io and University of Bristol (UK). 2010. C. 113-118.

[16] Inertial labs. Attitude and Heading Reference System AHRS-10 Datasheet. URL: https://inertiallabs.com/products/ahrs/.

\section{References:}

[1] Collin, J., Davidson, P., Kirkko-Jaakkola, M., Leppäkoski, H., "Inertial sensors and their applications. In Handbook of Signal Processing Systems", Springer, Cham, pp. 51-85, 2019.

[2] El-Sheimy, N., Youssef, A., "Inertial sensors technologies for navigation applications: state of the art and future trends", Satellite Navigation, 1(1), 2, 2020.

[3] Yatsyna, Y., Gridnev, Y., Shvedko, A., "Sravnitelnyiy analiz diskretnyih filtrov Kalmana i Madzhvika", Nauka $i$ innovatsii, 2 (168), 2017. [in Russian]

[4] Sergeenkov, D. D., "Eksperimentalnoe sravnenie algoritmov opredeleniya orientatsii dlya multikopterov", Mezhdunarodnyiy zhurnal informatsionnyih tehnologiy i energoeffektivnosti, 4 (2), 31-40, 2019. [in Russian]

[5] Korikov, A. M., Meshcheryakov, Ya.E., "Orientatsiya gornyih tehnologicheskih mashin na osnove mikroelektromehanicheskih sistem", Dokladyi Tomskogo gosudarstvennogo universiteta sistem upravleniya $i$ radioelektroniki, 21 (4), 2018. [in Russian]

[6] Meshcheryakov Ya.E. "Avtomatizatsiya protsessov monitoringa i pozitsionirovaniya funktsionalnyih elementov gornyih tehnologicheskih mashin: avtoref. dis. kand. tehn. nauk.", Tomsk, 2018. [in Russian]

[7] Radzivilov, G.D., \& Fesenko, O.D., "Kompensatsiia Pokhybok Inertsialnykh Vymiriuvalnykh Datchykiv MEMS Na Osnovi Filtra Madzhvika", Zbirnyk Naukovykh Prats Viiskovoho Instytutu Telekomunikatsii Ta Informatyzatsii, (1), 77-82, 2018. [in Ukrainian]

[8] Malinen, E., "Fusion of data from quadcopter's inertial measurement unit using complementary filter", Bachelor's Thesis, Lappeenranta University of Technology, Finland, 2015.

[9] Urdhwareshe, R., Bakshi, M., Naiknavare, P., Naik, S., "Design and implementation of IMU sensor fusion and PID control in quadrotor", Int. J. Electron. Commun, 2, 55-63, 2014.

[10] Mai, T. A., Dang, T. S., Anisimov, D. N., Fedorova, E., "Fuzzy-PID Controller for Two Wheels Balancing Robot Based on STM32 Microcontroller", In International Conference on Engineering Technologies and Computer Science (EnT), IEEE, pp. 20-24, 2019. DOI: 10.1109/EnT.2019.00009 
[11] Baerveldt, A. J., Klang, R., "A low-cost and low-weight attitude estimation system for an autonomous helicopter", In Proceedings of IEEE International Conference on Intelligent Engineering Systems, IEEE, pp. 391-395, 1997.

[12] Min, H. G., Jeung, E. T., "Complementary filter design for angle estimation using mems accelerometer and gyroscope", Department of Control and Instrumentation, Changwon National University, Changwon, Korea, 641$773,2015$.

[13] Gordeev V.N., (2016). "Kvaternionyi i bikvaternionyi s prilozheniyami v geometrii i mehanike", Izdatelstvo "Stal", Kiev, 316 p., 2016. ISBN 978-617-676-099-3.

[14] Perumal, L., "Quaternion and its application in rotation using sets of regions", International Journal of Engineering and Technology Innovation, 1(1), 35, 2011.

[15] Madgwick, S., "An efficient orientation filter for inertial and inertial/magnetic sensor arrays", Report x-io and University of Bristol (UK), 25, 113-118, 2010.

[16] Inertial labs. (2020). Attitude and Heading Reference System AHRS-10 Datasheet. Retrieved from: https://inertiallabs.com/products/ahrs/.

УДК 664.1: 65.011.56

\title{
АВТОМАТИЗАЦІЯ ОПЕРАТИВНОГО ОБЛІКУ ЦУКРОВОГО УТФЕЛЮ В МОДЕРНІЗОВАНІЙ СИСТЕМІ КЕРУВАННЯ ДЛЯ ПРОДУКТОВОГО ВІДДІЛЕННЯ ЦУКРОВОГО ЗАВОДУ
}

\section{Скаковський Ю. М.}

Одеська національна академія харчових технологій, Одеса, Україна

ORCID: http://orcid.org/0000-0003-4888-4469

yurysk@ukr.net

Copyright (C) 2020 by author and the journal "Automation of technological and business - processes. This work is licensed under the Creative Commons Attribution International License (CC BY). http://creativecommons.org/licanses/by/4.0

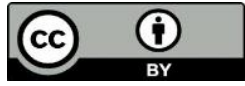

ONAFT

Open Access

DOI: https://doi.org/10.15673/atbp.v12i3.1922

\begin{abstract}
Анотація. Розглядаються технічні рішення з розробки підсистеми автоматичного оперативного обліку иукрового утфелю в модернізованій системі керування для продуктового відділення иукрового виробництва. Наведений аналіз відомих рімень із розробки аналогічних систем. Проведені лабораторні дослідження програми оперативного обліку иукрового утфелю, щчо був зварений у вакуум-апараті періодичної дї (ВА) протягом зміни. Програма була складена FBD подібною мовою програмування контролера МІК52 українського виробництва. Імітаційне моделювання підсистеми проводилось на спеціалізованому стенді із застосуванням промислових контролерів та програмних засобів украӥнського виробництва, в тому числі SCADA-системи «IНДЕЛ». Для зв'язку програмованого контролера та комп'ютера використаний перетворювач інтерфейсів MODBUS RTU - USB типу БПI-52. Наведені результати моделювання підсистеми оперативного обліку утфелю, аналіз котрих дозволяє зробити висновки про працездатність розроблених алгоритмів та програм. Інтегрування розробленої підсистеми обліку утфелю до системи автоматизованого керування (САК) прочесами у ВА дозволило розширити перелік функиій, шео виконуються у САК, та підвищити інтелектуальні можливості системи. Отримані позитивні результати проведеного дослідження дозволили сформувати рекомендації та пропозииії до модернізації АСКТП продуктового відділення, на основі методики автоматизованих розрахунків традиційних показників обліку виробництва иукрового заводу. Розроблена промислова версія АРМ оператора-варщика, котра запропонована до впровадження. Крім того, за отриманими результатами були визначені напрямки подальших досліджень САК технологічними процесами иукрового заводу.
\end{abstract}

Abstract. Technical solutions to develop the subsystem of automatic operational accounting for sugar massecuite in modernized control system for food department of sugar production are considered. The analysis of known solutions to develop similar systems was done. Laboratory studies of the program for operational accounting of sugar massecuite that was brewed in batch pan (VA) during the shift were conducted. The program was compiled in FBD-like programming language for 